Notes 


\title{
Investigating the Translation of Yahdi (Guide) in the Quran
}

\author{
Mahmoud Altarabin
}

\section{$\underline{\text { Abstract }}$}

The thirst for knowledge has brought people into contact with people of other cultures. Translation is the sole means to promote the cultural and religious exchange between different nations. However, linguistic, cultural and religious factors can affect the translation product. This paper aims to discuss the translation pitfalls resulting from translating the word yahdi (guide) into English. It is fair to assume that a translation product may entail loss of meaning as Baker (1992:57) argues. Such loss of meaning or failure to account for the possible connotations of words (yahdi in the context of this paper) may lead to undesirable results on the target reader. This study examines the implications of the failure to account for the connotations of yahdi (guide). The translation of the word has been examined in three main translations of the meaning of the Holy Quran: Sahih International, Pickthall and Yusuf Ali.

Keywords: the Quran, translation, equivalence, denotation, guide

\section{Equivalence at glance}

Equivalence is regarded as the controlling concept of most of the translation theories. Venuti $(2000: 121)$ says that the fifties of the 
twentieth century witnessed an opposition between translating for pragmatic equivalence and translating that is formally equivalent, aiming to reflect the linguistic and cultural features of the foreign text. A number of scholars argued for equivalence and others opposed to it. Catford (1965:21) says that "the central problem of translation practice is that of finding TL equivalents." The equivalence relation with the SL text is problematic (Hervey et al. 1995:14). Gentzler (1993:58) believes that equivalence is a rather a necessary and important term in the field of Translation Studies.

Baker and Saldanha (2008:96) argue that theorists like (Catford 1965, Nida and Taber 1969, Toury 1980, Pym 1992) define translation based on equivalence relations. Baker (1992: 5-6) explains that she uses the term equivalence "for the sake of convenience - because most of the translators are used to it rather than because it has any theoretical status". She believes that linguistic and cultural aspects influence equivalence and make it relative. Pym (1992:37) says that equivalence defines translation and translation, in turn, defines equivalence.

Equivalence relation has resulted in a considerable debate among translation theorists. Biguenet and Schulte (1989: xiii) believe that "an exact equivalence from one language to another will never be possible."They also believe that perfect translation is an impossible task (1989: vii). Gregory Rabassa (in Biguenet and Schulte 1989:1) stresses that "a translation can never equal the original." House (1997:24) stresses the importance of linguistic and extra-linguistic factors to specify, refine and modify the equivalence relation. Ivir (1996:155 in Hickey, 1998:63) argues that “equivalence is ... relative and not absolute."Catford (1965:21) says that the task of translation theory is to define the nature and conditions of translation equivalence. 
Equivalence becomes more challenging when dealing with religious or cultural texts. The values which the ST reflects may not be similar to those of the TT readers. Bassnett (2002:32) says "to attempt to impose the value system of the SL culture onto the TL culture is dangerous ground."Sapir says that "no two languages are very sufficiently similar to be considered as representing the same social reality."

Arabic and English reflect two different social, cultural, linguistic and religious backgrounds. The structure of Arabic is rich in that one word asa'altomoniha can represent a full sentence in English (Did you ask me for it?). On the other hand, an English term like outsourcing may be understood by the speakers of Arabic, yet it is not lexicalized and thus needs to be paraphrased to render the meaning. There are also English specific terms which have no 'exact equivalents' in any other language. An example of that is speaker in the 'speaker of the House of Commons'. On the cultural level, the translation of Allah (the only God) into English as God (any God) reflects the difference in the implication of the use of such term.

\section{Religious texts and the translator's role}

The translation of religious texts between two distinct languages, cultures and religions entails some challenges. Such may be attributed to the linguistic or religious variance. A concept, say divorce, exists in English and Arabic. However, translating the same from Arabic into English is challenging. The Islamic law distinguishes between talaqraj'I (revocable divorce) and talaqba' in (final divorce). An example of another term is iddah (this term refers to the period a woman must observe after the death of her husband or after a divorce, during which she may not marry another man). 
Such terms are culture specific and no direct equivalence is available for the same in any other language.

The translator in such a context shall be able to communicate the meaning of such specific terms. Hatim and Mason (1997:1) believe that a translator is "both a receiver and producer."They (1990:92) explain that the role of the translator includes constructing a model of source text intended meaning and evaluating its impacts on intended receivers. Nida (1964:145) says that a translator must have control over the language into which he is translating. "He cannot simply match words from a dictionary" (Nida,1964). Translators need to render texts which are easily understood by the target readers.

\section{Yahdi (guide): challenges and horizons}

This analysis of the three different translations of yahdi (guide and its derivations) attempts to show how the translators did not account for the type of guidance intended by the use of the word in different Quranic verses. We will cite three different translations of each intended meaning of the word.Al Salihi (p.209) explains that there are four different types of hidayah (guidance).

\section{Hidayah 'ammah (general guidance)}

This type of guidance is given to all creation through which they fulfill the purpose for which they were created. All people share this type of guidance regardless of their beliefs. This hidayah is referred to in the Quran 20:50:




Sahih International: He said, "Our Lord is He who gave each thing its form and then guided [it]."

Pickthall: He said: Our Lord is $\mathrm{He}$ Who gave unto everything its nature, thenguided it aright.

Yusuf Ali: He said: "Our Lord is He Who gave to each (created) thing its form and nature, and further, gave (it) guidance."

\section{Hidayat bayan (explanation guidance):}

In this type of guidance, the two paths of good and evil are defined and explained according to Islam. This is the type of hidayah referred to in the Quran 42:52:

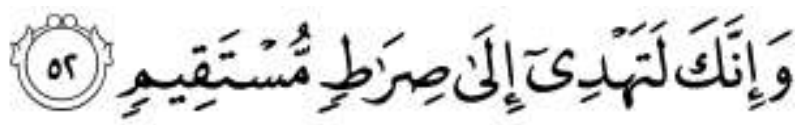

Sahih International: "And indeed, [O Muhammad], you guide to a straight path"

Pickthall: "And lo! thou verily dost guide unto a right path,"

Yusuf Ali: "and verily thou dost guide (men) to the Straight Way,"

III. Hidayattawfiq (a heavenly guidance). Allah inspires and guides some to the truth of faith. The type it refers to in the Quran 64:11:

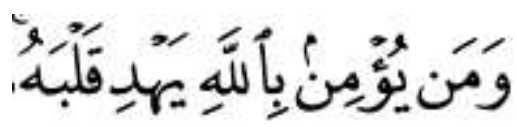


Sahih International: And whoever believes in Allah - He will guide his heart.

Pickthall: And whosoever believeth in Allah, He guideth his heart.

Yusuf Ali: and if any one believes in Allah, (Allah) guides his heart (aright).

IV. Hidayah in the next life. An example of this is reflected in the Quran 7:43

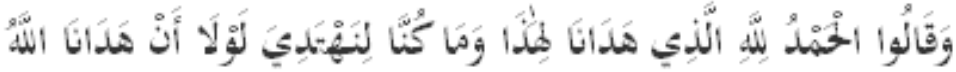

Sahih International: And they will say, "Praise to Allah , who has guided us to this; and we would never have been guided if Allah had not guided us."

Pickthall: The praise to Allah, Who hath guided us to this. We could not truly have been led aright if Allah had not guided us."

Yusuf Ali: and they shall say: "Praise be to Allah, who hath guided us to this (felicity): never could we have found guidance."

Sahih

\section{International}

Type 1 guided

Type 2 guide

Type 3 guide

Type 4 guided

\section{Pickthall Yusuf Ali}

guided guidance

guide

guide

guideth

guide

guided

guided 


\section{Commentary}

The different derivations of yahdi in the above four types were mentioned around 269 times in the Quran. The first type of guidance is general and is bestowed on all creations. None of the translators reflected this meaning while rendering the word into English. This type of guidance resembles the natural instinct which drives creations to fulfill certain tasks.

The second type of guidance is specific in that a human may guide another human through explanation and teaching. This is related to showing the good path from the evil path. The third type of guidance is more specific in which Allah guides those who follow His path. The fourth type is inevitable on the judgment day.

The translations of the word in English did not account for any of these types of hidayah. Given that the word has different implications in Arabic, the same can be accounted for in English through the use of a note to indicate which type of guidance the word refers to in a given context. This can overcome the pitfall of failure to account for the different connotations of the word. By way of concluding this paper, it is essential to assume that it is possible to render any type of text into other languages using different strategies which can facilitate accounting for the intended meaning of the ST items.

\section{References:}

Al Salihi, A. Al Dhu' Al Muneer ala Al Tafseer [Insight into Interpretation].Riyadh: Al Noor for Printing.

Baker, M. (1992).In Other Words: A Coursebook on Translation. London: Routledge. 
Baker, M. and Saldanha, G. (Eds.). (2008).Routledge Encyclopedia of Translation Studies ( ${ }^{\text {nd }}$ edition).London and New York: Rutledge.

Bassnett.S. (2002).Translation Studies: New Accents ( $3^{\text {rd }}$ edition). London and New York: Routledge.

Bassnett.S. (2002).Translation Studies: New Accents ( $3^{\text {rd }}$ edition). London and New York: Routledge.

Biguenet, John and Schulte, Rainer. (Eds.). (1989). The Craft of Translation. Chicago and London: The University of Chicago Press.

Catford,J. C.(1965). A Linguistic Theory of Translation.London: Oxford University Press.

Catford,J. C.(1965). A Linguistic Theory of Translation.London: Oxford University Press.

Gentzler, E. (1993). Contemporary Translation Theories. London and New York: Routledge.

Hatim, B., and Mason I. (1990). Discourse and the Translator. London and New York: Longman.

Hatim, B. and Mason I. (1997). The Translator as Communicator. London and New York: Routledge.

Hervey, S., Higgins, I., and Haywood, L. M. (1995). Thinking Spanish Translation: A Course in Translation Method: Spanish into English. London and New York: Routledge. 
Mahmoud Altarabin

Hickey, L. (1998).The Pragmatics of Translation.Philadelphia: Multilingual Matters.

House, J. (1997). Translation Quality Assessment: A Model Revisited. Tubingen: Narr.

Nida, E. (1964). Towards a Science of Translation. Leiden: Brill.

Pym, A. (1992). Translation and Text Transfer: An Essay on the principles of intercultural communication. Frankfurt am Main: Peter Lang.

Venuti, L. (ed.) (2000). The Translation Studies Reader. London and New York: Routledge. 